\title{
ANALISIS KEPUASAN PELANGGAN PEMBUATAN SERTIFIKAT TANAH DENGAN MENGGUNAKAN SERVQUAL DAN KANSEI ENGINEERING BERDASARKAN TWITTER BPN SALATIGA
}

\author{
Juwita Artanti Kusumaningtyas ${ }^{1}$, Eko Sediyono ${ }^{2}$ \\ 1,2Universitas Kristen Satya Wacana \\ Email: ${ }^{1}$ mee.juwita@gmail.com, ${ }^{2}$ ekosed1@yahoo.com
}

(Naskah masuk: 10 Mei 2017, diterima untuk diterbitkan: 14 Agustus 2017)

\begin{abstract}
Abstrak
BPN (Badan Pertanahan Nasional) merupakan instansi pemerintah dengan tugas di bidang pertanahan sesuai dengan Peraturan Presiden Republik Indonesia Nomor 20 Tahun 2015. Salah satu tugas BPN yaitu melaksanakan kebijakan penetapan hak tanah, pendaftaran tanah, dan pemberdayaan masyarakat. Fungsi tugas pendaftaran dan penetapan hak tanah tertuang dalam salah satunya pelayanan BPN yaitu pembuatan sertifikat tanah. Pemberdayaan masyarakat sendiri dilakukan BPN Salatiga dengan memanfaatkan media sosial twitter untuk berbagi informasi kepada masyarakat terkait program kerja dan pelayanan. Melalui twitter BPN Salatiga, masyarakat dapat mengetahui pelayanan BPN Salatiga dan menjadi forum diskusi masyakarat dengan pihak BPN, sehingga dapat mengetahui keluhan dan harapan masyarakat terhadap pelayanan BPN Salatiga khususnya mengenai sertifikat tanah. Berdasarkan tweet BPN Salatiga ada 20 atribut layanan yang akan diolah dengan metode Servqual dan menggunakan metode Kansei Engineering untuk melakukan perbaikan. Analisis ini diharapkan dapat memberi pandangan kepada BPN untuk mengetahui kualitas pelayanan yang diberikan kepada pelanggan dan mengetahui kepuasan pelanggan terhadap pelayanan sertifikat tanah melalui twitter BPN Salatiga. Hasilnya tingkat harapan tertinggi ada pada dimensi Tangible $(4,50)$ dan persepsi tertinggi pada dimensi Reliability $(4,49)$ dengan 12 kansei words.
\end{abstract}

Kata kunci: Kepuasan Pelanggan, Servqual, Kansei Engineering, Twitter

\begin{abstract}
BPN (National Land Agency) is a government agency with a task in the field of land in accordance with the Presidential Regulation of the Republic of Indonesia No. 20 of 2015. One of the duties of BPN is implementing the policy of land titling, land registration, and community empowerment. The function of registration and assignment of land rights is contained in one of the BPN services namely the making of land certificate. Community empowerment itself is done by BPN Salatiga by utilizing social media twitter to share information to the community related to work program and service. Through twitter BPN Salatiga, the public can know the service of BPN Salatiga and become a forum of community discussions with the BPN, so it can know the complaints and expectations of the community on the service of Salatiga BPN especially regarding the land certificate. Based on Salatiga BPN tweet there are 20 service attributes that will be processed by Servqual method and using Kansei Engineering method to make improvements. This analysis is expected to give a view to $B P N$ to know the quality of services provided to customers and know customer satisfaction with the service of land certificate through twitter BPN Salatiga. The result is the highest expectation level in Tangible dimension (4.50) and highest perception on Reliability dimension (4.49) with 12 kansei words.
\end{abstract}

Keywords: Customer Satisfaction, Servqual, Kansei Engineering, Twitter 


\section{PENDAHULUAN}

BPN (Badan Pertanahan Nasional) merupakan Lembaga Pemerintah Non Kementrian yang bertanggung jawab kepada Presiden dan dipimpin oleh Kepala (sesuai dengan Perpres No. 63 Tahun 2013). Berdasarkan website BPN (www.bpn.go.id), BPN bertugas di bidang pertanahan secara nasional, regional dan sektoral sesuai dengan ketentuan peraturan perundang-undangan.

Salah satu tugas fungsi BPN yaitu merumuskan dan melakukan kebijakan penetapan hak tanah, pendaftaran tanah, dan pemberdayaan masyarakat, Pelayanan BPN khususnya di Salatiga dalam mewujudkan salah satu fungsi tugas BPN yaitu memberikan pelayanan pembuatan sertifikat tanah sesuai harapan pemohon. Pelayanan ini dilakukan pemohon dengan mengunjungi loket yang ada pada kantor BPN atau menggunakan jasa notaris untuk menyelesaikan proses pembuatan sertifikat tanah. Selama proses pembuatan sertifikat tanah, pemohon dapat memanfaatkan fasilitas BPN secara online yang digunakan untuk memantau proses pembuatan sertifikat tanah yang diaplikasikan pada smartphone bernama "Sentuh". Sedangkan untuk fungsi tugas BPN terkait pemberdayaan masyarakat, BPN Salatiga memiliki berbagai program kerja untuk masyarakat yang semuanya di-share melalui media sosial twitter. Media Sosial Twitter BPN Salatiga juga dijadikan forum untuk forum diskusi secara online oleh masyarakat.

Sesuai dengan 11 Agenda Kebijakan BPN, pelayanan dikatakan baik jika dapat membangun kepercayaan masyarakat kepada BPN dengan mengetahui respon pelanggan terhadap pelayanan BPN sebagai kepuasan pelanggan. Cara mengetahui kepuasan pelanggan yaitu melakukan analisis pelayanan BPN dengan mengukur harapan, kerja nyata, tingkat kepentingan pelayanan, hingga rekomendasi terhadap pelayanan BPN. Oleh sebab itu penelitian ini menggunakan metode Servqual (Service Quality) dan Kansei Engineering.

Penelitian ini diharapkan dapat memberi informasi kepada BPN mengenai respon tingkat pelayanan yang sudah dan mengetahui kualitas pelayanan yang diberikan kepada pelanggan dengan hasil tingkat kepuasan pelanggan. Berdasarkan hasil kepuasan pelanggan, diharapkan dapat memberi wacana pelayanan yang perlu dipertahankan dan dikembangkan serta pelayanan yang masih perlu dilakukan perbaikan untuk meningkatkan kualitas pelayanan BPN Salatiga.

\section{KAJIAN PUSTAKA}

Penelitian mengenai kualitas pelayanan dan kepuasan pelanggan sudah banyak dilakukan, diantaranya adalah penelitian menggunakan perspektif Servqual dengan 5 dimensi untuk mengetahui kualitas layanan. Penelitian ini menggunakan kuesioner sebagai pengumpulan data dengan memanfaatkan model Kano sebagai pengukuran kepuasan pelanggan. Kesimpulan ketika menggunakan dua metode ini menunjukkan kepuasan pelanggan dipengaruhi oleh klasifikasi atribut. (Sulisworo\&Maniquiz,2012) Keterkaitan dengan penelitian ini yaitu penggunaan metode Servqual dengan 5 dimensi untuk menentukan jenis layanan. Perbedaannya, penelitian ini menggunakan metode Servqual yang dikombinasikan dengan metode Kansei Engineering.

Penelitian dengan topik pembahasan kepuasan pelanggan juga terdapat pada penelitian selanjutnya untuk peningkatan kualitas pelayanan dengan menggunakan metode Servqual dan Triz. Metode Servqual digunakan untuk menganalisa masalah yang terjadi sedangkan Triz digunakan sebagai solusi usulan perbaikan kualitas pelayanan di PT. XYZ. Hasilnya berupa rekomendasi yang diberikan kepada PT. XYZ salah satunya dengan memisahkan dan mengklasifikasikan barang-barang yang akan dikirim menjadi beberapa kategori dan memberikan pelatihan secara berkala kepada staf serta memberikan reward kepada staf. (Erni,2014) Keterkaitan dengan penelitian ini yaitu penggunaan Servqual dan Triz untuk mengukur kepuasan pelanggan. Perbedaannya, penelitian ini mengintegrasikan Servqual dan Kansei Engineering untuk mengukur kepuasan pelanggan.

Selain itu, penelitian terdahulu yang menggunakan metode Kansei Engineering juga terdapat pada penelitian yang membantu mengidentifikasi produk untuk melakukan penulusuran terhadap harapan dan keinginan konsumen terhadap suatu kemasan produk. Penelitian tidak hanya memfokuskan berdasarkan perasaan psikologi konsumen saja, namun juga memetakan atribut produk berdasarkan performasinya. Sehingga metode yang digunakan yaitu Kansei Engineering didukung dengan model Kano. Hasil penelitian ini adalah mengintegrasikan kedua metode untuk mengetahui desain yang sesuai dengan citra dan perasaan konsumen dengan desain kategori Kano. (Haryono\&Baryah, 2014) Keterkaitan dengan penelitian ini yaitu menganalisa kepuasaan pelanggan dengan menggabungkan metode Kansei Engineering dan metode kepuasan pelanggan yang lain. Perbedaannya, penelitian ini tidak menggabungkan metode Kansei Engineering dan mosel Kano, metode yang digunakan dengan memanfaatkan model Servqual dan Kansei Engineering untuk dikolaborasikan.

Penelitian selanjutnya, menerapkan metode Kansei Engineering untuk mengidentifikasi perancangan desain untuk souvenir khas Malang. Tujuan yang akan diperoleh dari penilitian ini adalah dihasilkan inovasi-inovasi baru untuk desain souvenir berbahan dasar kayu yang benar-benar khas Malang. Temuan yang dihasilkan dari penelitian ini adalah dengan menerapkan metode Kansei 
Engineering, makan akan memperoleh poin-poin atribut desain dalam perancangan souvenir khas Malang (Rofieq,2014). Keterkaitan dengan penelitian ini yaitu menggunakan metode Kansei Engineering untuk mengukur kepuasan pelanggan. Perbedaannya, penelitian ini menambahkan pengumpulan data menggunakan sosial media twitter untuk mendapatkan kansei words dan mengkolaborasikan dengan metode Servqual.

Kajian pustaka pada penelitian ini tidak hanya melihat dari penelitian terdahulu, namun juga melihat dari dasar teori yang terkait dengan topik pembahasan. Dasar teori dikutip dari para pakar yang terdapat pada jurnal penelitian dan buku. Teori yang terkait dengan penelitian ini yaitu mengenai kepuasan pelanggan, metode Servqual, dan Kansei Engineering.

Kepuasan pelanggan menurut Armistead, Pritchard, dan Machin merupakan proses bisnis manajemen yang didasarkan serangkaian pelayanan sebagai hal yang penting untuk keselarasan kepuasan pelanggan (Maddem). Kepuasan pelanggan menurut Gomez et al didefinisikan dan diukur sebagai penilaian konsumen terhadap suatu atribut tertentu (Suchanek,2014).

Service Quality digunakan untuk mendefinisikan kualitas pelayanan sejauh mana layanan tersebut memenuhi kebutuhan pelanggan atau harapan pelanggan (Sahin). Servqual juga didasarkan pada proposisi bahwa kualitas pelayanan dapat diukur dengan kesenjangan atau gap antara layanan yang diharapkan pelanggan dan kinerja yang diterima pelanggan (Landrum,2009). Metode Servqual terdiri dari 5 dimensi kualitas pelayanan, sebagai berikut : 1) Reliability (keandalan), berfokus kepada pelayanan yang dijanjikan secara akurat dan handal. 2) Assurance (jaminan), berfokus kepada perilaku karyawan yang sopan dan berpengetahuan luas sehingga memberikan rasa percaya serta keyakinan. 3) Tangibles (bukti terukur), berfokus kepada fasilitas fisik, perlengkapan, dan tampilan dari personalia serta kehadiran para pengguna. 4) Empathy (empati), berfokus kepada kepedulian serta perhatian kepada masing-masing pengguna. 5) Responsiveness (daya tanggap), berfokus kepada kesanggupan untuk membantu pelanggan serta memberikan perhatian yang tepat (Djunaidi,dkk).

Metode yang digunakan selanjutnya yaitu metode Kansei Engineering. Menurut Nagamachi, metode Kansei Engineering dianggap unggul dibandingkan dengan metode-metode serupa lainnya. Metode ini mampu menerjemahkan kebutuhan emosional pelanggan ke dalam parameter atribut produk melalui rekayasa (Hartono,2012). Prosedur standard dalam pendekatan Kansei Engineering terdiri dari 4 langkah yaitu : 1) Identifikasi suatu produk akan kebutuhan konsumen dari segi images dan ergonomis berdasarkan perasaan psikologis. 2) Ekstraksi parameter produk agar dapat memuaskan calon konsumen. 3)
Pengembangan Kansei Engineering untuk mendapatkan teknologi egronomis. 4) Melakukan penyesuaian desain suatu produk berdasarkan preferensi konsumen dan kelompok sosial (Mu'alim\&Hidayat,2014).

\section{METODE PENELITIAN}

\subsection{Pemilihan Sampel}

Teknik pengambilan sampel merupakan upaya penelitian untuk mendapat sampel yang representatif (mewakili), yang dapat menggambarkan populasinya. Teknik pengambilan sampel dibagi atas 2 kelompok besar yaitu Probability Sampling dan Non Probability Sampling (Nasution,2003). Pemilihan pengambilan sampel data pada penelitian ini dengan menerapkan Teknik Non Probability Sampling. Teknik Non Random Sampling (non probability sampling) adalah cara pengambilan sampel yang tidak semua anggota dari populasi tersebut memiliki kesempatan yang sama untuk dipilih menjadi sampel penelitian dengan convience sampling (pemilihan unit analisa disesuaikan dengan penelitian), porposive sampling (berdasarkan pertimbangan dalam pengambilan sampel), dan quota sampling (Hasibuan,2007). Alasan teknik Non Probability Sampling yang dipilih karena unit pembagian kuesioner sudah ditentukan, yaitu di BPN Salatiga, Notaris, dan pengguna jasa BPN dalam pembuatan sertifikat tanah sebanyak 70 responden terdiri dari Pegawai Negeri, Swasta, Auditor, Pegawai Tidak Tetap, Ibu rumah tangga, dan Wiraswasta. Wawancara dilakukan kepada pegawai BPN Salatiga dan pemohon yang mendatangi BPN Salatiga. Sedangkan data twitter BPN Salatiga diambil mulai bulan Februari sampai Oktober 2016

\subsection{Teknik dan Langkah-langkah Analis}

Teknik analisis dan pengumpulan data yang digunakan dalam penelitian ini menggunakan teknik kuantitatif. Teknik kuantitatif pada dasarnya merupakan suatu pengamatan yang melibatkan suatu ciri tertentu berupa perhitungan, angka atau kuantitas (Hermansyah,2014).

Metode Servqual digunakan untuk menentukan atribut penilaian layanan dari BPN Salatiga yang nantinya akan menjadi pertanyaan untuk kuesioner. Atribut yang ditentukan berdasarkan analisis tweet BPN Salatiga dan hasil wawancara non-formal kepada pihak BPN yang berkaitan dengan pelayanan pembuatan sertifikat tanah. Sehingga dari penggabungan tren topik berdasarkan tweet BPN Salatiga terkait sertifikat tanah dan wawancara non-formal, maka dihasilkan pertanyaan-pertanyaan yang digunakan untuk kuesioner sebanyak 20 pertanyaan atribut dan dikelompokkan berdasarkan 5 dimensi Servqual. Komposisi atribut-atribut tersebut terdiri dari 5 atribut Tangible, 4 atribut Reliability, 3 atribut Responsiveness, 4 atribut Assurance, dan 4 atribut 
Empathy. Atribut layanan akan dibagikan kepada responden sebagai kuesioner dengan skala Likert 1-5 dengan perincian sebagai berikut : (1) (STB) Sangat Tidak Baik, (2) (TB) Tidak Baik, (3) (CB) Cukup Baik, (4) (B) Baik, (5) (SB) Sangat Baik. Hasil dari data kuesioner akan dilakukan analisis dengan memperoleh nilai kepuasan atau persepsi pelanggan dan prioritas kepentingan pelayanan yang diharapkan oleh responden. Hasil analisis kuesioner menunjukkan Gap antara harapan dan pelayanan nyata dari pelanggan terhadap BPN Salatiga

Langkah selanjutnya menggunakan metode Kansei Enggineering. Metode ini digunakan untuk mengukur secara responden secara psikologis terhadap pelayanan BPN Salatiga berdasarkan Kansei words. Kansei words dipilih berdasarkan pertanyaan kuesioner, hasil wawancara non-formal, dan data pada twitter BPN Salatiga yang membahas mengenai sertifikat tanah. Penilaian menggunakan skala Likert 1-5 untuk setiap kosa kata yang menggambarkan pelayanan BPN Salatiga. Nilai 1 menunjukkan penilaian paling negatif, dan Nilai 5 menunjukkan penilaian paling positif.

Hasil Servqual dan Kansei words akan dilakukan analisis dengan menggunakan Regresi Linier Berganda dengan metode stepwise. Kansei words sebagai variable dependen, dan atribut layanan Servqual sebagai variable independen. Hal ini untuk mengetahui keterkaitan antara Servqual dan Kansei words. Selanjutnya, akan didapatkan hasil kepuasan pelanggan baik secara analisis kuesioner yang berupa pertanyaan mengenai pelayanan BPN Salatiga terkait sertifikat tanah dan kepuasan pelanggan dengan menggunakan analisis emosi atau psikologis dari responden.

\section{HASIL DAN PEMBAHASAN}

\subsection{Responden Terpilih}

Awal pengumpulan data dilakukan dengan membagikan kuesioner kepada responden yang dikelompokkan berdasarkan jenis kelamin, usia, dan jenis pekerjaan. Sesuai dengan Teknik Sampling yang terpilih yaitu Non Probability Sampling, maka unit yang ditentukan untuk membagikan kuesioner adalah di BPN Salatiga, Notaris dan pengguna jasa BPN di Salatiga sebanyak 70 responden. Responden tersebut dibagi menjadi 3 kelompok, yaitu kelompok usia, jenis kelamin, dan pekerjaan. Presentase terbanyak berdasarkan jenis kelamin responden yaitu $54.29 \%$ adalah pria. Sedangkan untuk wanita memiliki presentase $45.71 \%$. Sedangkan presentase terbesar responden berdasarkan usia berada pada kelompok usia 31-35 tahun dengan presentase 41.43\%. Jenis pekerjaan responden berisi kelompok responden dengan presentase terbesar yaitu Pegawai Negeri dengan $32.86 \%$.

\subsection{Hasil Analisis Data 4.2.1 Analisis Servqual}

Pertanyaan kuesioner yang terdiri dari 20 atribut layanan, masing-masing dianalisis untuk mengetahui respon dari masyarakat dilihat dari nilai harapan masyarakat dan nilai kerja nyata BPN Salatiga dari sudut pandang masyarakat. Selanjutnya, hasil analisis ini digunakan untuk mengetahui nilai tertinggi dari 5 dimensi Servqual oleh pemohon. Hasil analisis digambarkan dalam bentuk grafik perbandingan terhadap rata-rata tingkat persepsi dan tingkat harapan. Persepsi adalah kepuasan atau kerja nyata yang didapat pemohon pada saat mendapat layanan di BPN Salatiga. Harapan adalah keinginan pelanggan yang didapatkan dari layanan BPN Salatiga.

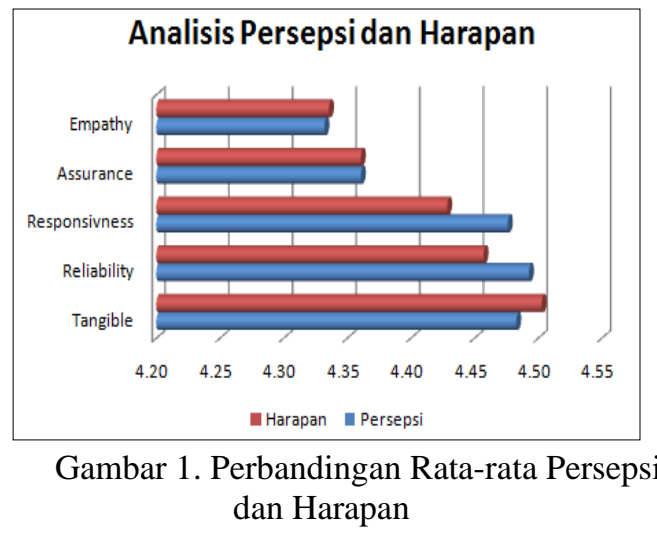

Berdasarkan gambar Perbandingan Rata-rata Persepsi dan Harapan, tingkat Harapan tertinggi ada pada dimensi Tangible dengan nilai 4,50. Sedangkan tingkat Persepsi tertinggi ada pada dimensi Reliability (4.49).

Hal ini menunjukkan Gap antara persepsi/ kepuasan dengan harapan pemohon ada pada dimensi Tangible dan Empathy. Karena itu pihak BPN Salatiga perlu melakukan perbaikan dalam fasilitas fisik, perlengkapan, dan keterampilan personalia kepada pemohon (Tangible) serta meningkatkan perhatian dan kepedulian kepada pemohon (Empathy). Perbaikan dapat dilakukan dengan melihat diagram Kartesius untuk mengetahui perbaikan yang perlu dilakukan berdasarkan atribut Servqual.

\subsubsection{Analisis Kansei Engineering}

Analisis ini digunakan untuk mengetahui kesan secara psikologi pemohon terhadap pelayanan BPN Salatiga. Hasil analisis dapat dilihat melalui perhitungan Mean Kansei Words yang sudah ditentukan dari tweet di twitter BPN Salatiga pada kuesioner mengenai layanan sertifikat tanah.

Tabel 1. Perhitungan Mean Kansei Words

\begin{tabular}{lccccccc}
\hline Kansei & \multicolumn{4}{c}{ Nilai } & & Tota & Mea \\
Words & 1 & 2 & 3 & 4 & 5 & 1 & $n$ \\
\hline \multirow{2}{*}{ Cepat } & & & & 2 & 3 & & \\
& 0 & 0 & 8 & 5 & 7 & 70 & 4.41
\end{tabular}


158 Jurnal Teknologi Informasi dan Ilmu Komputer (JTIIK), Vol. 4, No. 3, September 2017, hlm. 154-159

\begin{tabular}{llllllll} 
Jelas & 0 & 0 & 3 & 2 & 5 & 70 & 4.46 \\
Mudah & 0 & 0 & 6 & 5 & 9 & 70 & 4.47 \\
& & & & 2 & 3 & & \\
Tanggap & 0 & 0 & 7 & 6 & 7 & 70 & 4.43 \\
Tepat & 0 & 0 & 4 & 3 & 3 & 70 & 4.41 \\
& & & & 2 & 4 & & \\
Teliti & 0 & 0 & 1 & 6 & 3 & 70 & 4.60 \\
& 0 & 0 & 2 & 3 & 3 & 70 & 4.49 \\
Nyaman & 0 & 6 & & \\
Terampil & 0 & 0 & 3 & 3 & 4 & 70 & 4.44 \\
& & & & 3 & 3 & & \\
Percaya & 0 & 0 & 0 & 1 & 9 & 70 & 4.56 \\
& & & & 3 & 3 & & \\
Kreatif & 0 & 0 & 2 & 0 & 8 & 70 & 4.51 \\
Tanggun & & & & 3 & 3 & & \\
g & 0 & 0 & 5 & 1 & 4 & 70 & 4.41 \\
jawab & & & & 3 & 3 & & \\
Bersih & 0 & 0 & 4 & 0 & 6 & 70 & 4.46 \\
\hline
\end{tabular}

Hasil mean Kansei Engineering dengan nilai tertinggi yaitu "Teliti" $(4,60)$. Hal ini menunjukkan mayoritas pemohon merasa puas dengan kecermatan dan ketelitian dalam pelayanan terhadap pemohon. Sedangkan nilai terendah dengan nilai yang sama yaitu "Cepat", "Tepat", dan "Tanggung jawab" $(4,41)$ perlu dilakukan peningkatan pelayanan supaya pemohon lebih merasakan kesan tersebut.

\subsubsection{Analisis Hubungan Servqual dan Kansei Engineering}

Analisisi ini digunakan untuk mencari keterkaitan atribut Servqual dan Kansei Words dengan menggunakan SPSS 16.0. Pemodelan yang digunakan yaitu Regresi Linear Berganda dengan metode stepwise. Kansei words berfungsi sebagai variabel dependen, sedangkan atribut layanan Servqual sebagai variabel independen.

Hasil Coefficient atribut persepsi thitung = 2.244 dengan probabilitas $=0.035<0.05$, menunjukkan adanya pengaruh yang signifikan antara atribut Servqual dan Kansei words. Hubungan Servqual dan Kansei Engineering dapat dilihat sebagai berikut:

Tabel 2. Hubungan Servqual dan Kansei

\begin{tabular}{|c|c|c|c|}
\hline \multicolumn{4}{|c|}{ Engineering } \\
\hline $\begin{array}{l}\text { Kansei } \\
\text { Words }\end{array}$ & $\begin{array}{l}\text { Mean } \\
\text { Kansei } \\
\text { Words } \\
(4,47)\end{array}$ & $\begin{array}{c}\text { Mean } \\
\text { Tingka } \\
\text { t } \\
\text { Kepent } \\
\text { ingan } \\
(4,42)\end{array}$ & Atribut \\
\hline Cepat & 4,41 & $\begin{array}{l}4.47 \\
4.53\end{array}$ & $\begin{array}{l}\text { Proses pembayaran cepat } \\
\text { dan mudah (9) } \\
\text { Kejelasan dalam } \\
\text { menyelesaikan } \\
\text { permasalahan pengukuran }\end{array}$ \\
\hline
\end{tabular}

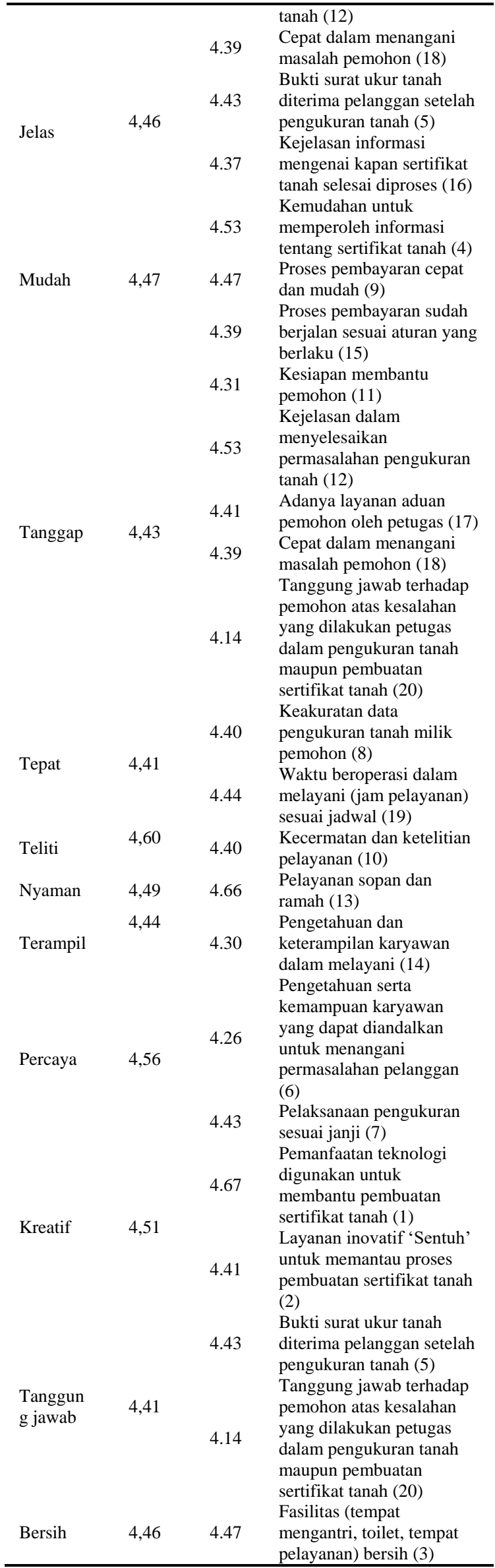


Setiap kansei words dapat mewakili beberapa atribut pelayanan yang mempengaruhi emosi pelanggan. Kolom Kansei words terdiri dari kosa kata untuk menilai kepuasan pelanggan berdasarkan psikologi masyarakat yang terukur dalam kolom Mean Kansei words. Rata-rata keseluruhan dari mean kansei words yaitu 4,47. Sehingga jika masing-masing kansei words memiliki rata-rata $\geq$ 4,47, maka kosa kata tersebut mewakili respon masyarakat terhadap pelayanan BPN Salatiga khususnya sertifikat tanah. Kosa kata yang mewakili yaitu "Mudah", "Teliti", "Nyaman", "Percaya", dan "Kreatif". Kolom Mean Tingkat kepentingan ini memiliki rata-rata keseluruhan 4,42. Atribut yang memiliki rata-rata diatas rata-rata tingkat kepentingan menunjukkan bahwa atribut layanan tersebut penting untuk diperhatikan oleh BPN Salatiga.

Mengetahui pengaruh layanan terhadap kepuasan pelanggan yang diberikan BPN Salatiga dilihat berdasarkan tingkat kepentingan dan tingkat kansei words yang mempengaruhi. Jika tingkat kansei words lebih tinggi dari rata-rata kansei words, dan tingkat kepentingan melebihi rata-rata tingkat kepentingan, maka layanan tersebut membawa pengaruh terhadap kepuasan pelanggan. Atribut yang mempengaruhi kepuasan pelanggan yaitu atribut : (1), (4), (7), (9), (13).

\section{KESIMPULAN}

Kesimpulan penelitian ini yaitu : 1) Atribut dengan tingkat harapan tertinggi berdasarkan twitter dan layanan BPN Salatiga yaitu dimensi Tangible $(4,50)$. Tingkat persepsi tertinggi yaitu dimensi Reliability (4,49). 2) Hasil mean Kansei Engineering dengan nilai tertinggi yaitu "Teliti" $(4,60)$ yang menunjukkan faktor ketelitian memiliki pengaruh psikologis terhadap kepuasan pelanggan. 3) Atribut yang mempengaruhi kepuasan pelanggan berdasarkan hasil hubungan Servqual dan Kansei Engineering adalah atribut (1), (4), (7), (9), dan (13).

\section{DAFTAR PUSTAKA}

SULISWORO. D, and MANIQUIZ. N, 2012, Integrating Kano's Model and Servqual to Improve Healthcare Service Quality, Ahmad Dahlan University, pp.130-144

ERNI. N,dkk, 2014, Peningkatan Kualitas Pelayanan Dengan Metode Servqual Dan triz Di Pt. XYZ, Jurnal Ilmiah Teknik Industri, Vol. 2, No. 2, pp 92-100

HARYONO. M dan BARIYAH. C, 2014, Perancangan Konsep Produk Alas Kaki Dengan Menggunakan Integrasi Metode Kansei Engineering Dan Model Kano, JITI, pp.71-82

ROFIEQ. M, dkk, 2014, Penerapan Metode Kansei Engineering Guna Mengidentifikasi Atribut Desain Dalam Perancangan Souvenir Khas
Malang, FT UMS: Simpsosium Nasional RAPI XIII, ISSN: 1412-9612

MADDERN. H, et.al, Customer Satisfaction And Service Quality in UK Financial Services, International Journal of Production and Operations Management, University of Exeter. No. 07/10

SUCHANEK. P, et.al, 2014, Customer Satisfaction, Product Quality and Performance of Companies, Narodohospodarsky Obzor, Vol.14, Issue 4, pp.329-344

SHAHIN. A, Servqual and Model of Service Quality Gaps: A Framework for Determining and Prioritizing Critical Factors in Delivering Quality Services, pp.1-10

LANDRUM. H, et.al, 2009, Measuring IS System Service Quality with Servqual: User's Perceptions of Relative Importance of the Five Servperf Dimensions, International Journal of an Emerging Transdiscipline, Vol.12

DJUNAIDI. M, dkk, Analisis Kepuasan Pelanggan Dengan Pendekatan Fuzzy Service Quality Dalam Upaya Peningkatan Kualitas Pelayanan, pp.139-146

HARTONO. M, 2012, Kerangka Konseptual Integrasi Servqual, Model Kano Dan Kansei Engineering Dengan QFD Pada Industri Jasa, Industrial Engineering Conference (IEC)

MU'ALIM dan HIDAYAT. R, 2014, Re-Desain Kemasan dengan Metode Kansei Engineering, Al-Azhar Indonesia Seri Sains dan Teknologi, Vol.2, No.4

NASUTION. R, 2003, Teknik Sampling, Universitas Sumatera Utara, USU Digital Library, pp 17

HASIBUAN. Z.A, 2007, Metodologi Penelitian Pada Bidang Ilmu Komputer dan Teknologi Informasi, Depok : Universitas Indonesia

HERMANSYAH. M, dkk, 2014, Measurement of Consumer Satisfaction to The Service Quality of Oyster Mushroom Processed Product Use Servqual Method (A Case Study at CV. Sego Njamoer of Branch Outlet Malang), Universitas Brawijaya, pp.1-9 